\title{
Fiscal Sustainability of Japanese Prefectural Government Debt
}

\author{
Rena Akamatsu, Kazuki Hiraga* \\ School of Political Science and Economics, Tokai University, Kanagawa, Japan \\ Email: ${ }^{*}$ khiraga581470@gmail.com
}

Received 23 July 2015; accepted 15 August 2015; published 18 August 2015

Copyright (C) 2015 by authors and Scientific Research Publishing Inc.

This work is licensed under the Creative Commons Attribution International License (CC BY).

http://creativecommons.org/licenses/by/4.0/

(c) (i) Open Access

\begin{abstract}
This paper investigates whether the Japanese local government debt is sustainable. We apply the fiscal stabilization rule that each local government improves their primary balance in the current year when they issue additional debt the previous year. We check it using panel data of the Japanese prefectural governments. We find that Japanese prefectural governments were not sustainable across 1956-2007, though were sustainable across 1956-1989.
\end{abstract}

\section{Keywords}

\section{Prefectural Government, Fiscal Sustainability, Fiscal Stabilization Rule}

\section{Introduction}

In Japan, as in other countries, the recession caused by the subprime loan crisis has reduced tax revenues and necessitated additional government expenditures. Meanwhile, debt crises in Greece, Ireland, and Portugal have focused on financial reform in the EU. Japan's ratio of central and local government debt to GDP is relatively high compared to other OECD countries (Figure 1), and national financial reform has become a major debate in Japan. Furthermore, fiscal problems among municipalities and prefectures have been a topic of sustained discussion in Japan. In Kochi Prefecture in July 2004, the Prefectural Governor Daijiro Hashimoto declared a financial crisis during an address to the regular prefectural assembly and asserted that Kochi would face fiscal reconstruction in 2007 if conditions remained unchanged. In March 2007, the designated organization for fiscal secondary reconstruction in Yubari City, Hokkaido, highlighted the increased need to reform finances. More recently, it was said that Okayama and Miyagi Prefectures would be organized for fiscal reconstruction until 2011 in $2008^{1}$. Given these discussions, it is timely to consider the fiscal sustainability of Japan's prefectural governments.

\footnotetext{
${ }^{*}$ Corresponding author.

${ }^{1}$ As for Okayama prefecture, prefectural governor Masahiro Ishii mentioned it in May 29, 2008. Miyagi prefecture issued "Third fiscal reconstruction program” in 2008.
} 


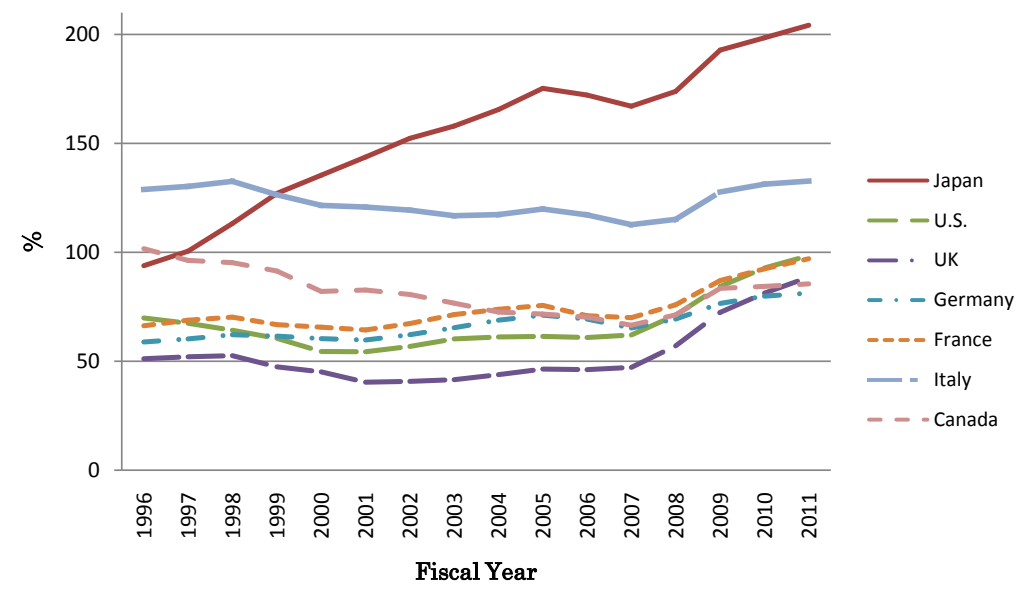

Figure 1. International comparison (National Plus Local Debt/GPP). Source: OECD Economic Outlook.

This paper investigates whether the Japanese prefectural government debt is sustainable or not, applying the empirical analysis of the debt stabilization rule á la Bohn (1998) [2] and Mendoza and Ostry (2008) [7]. We find that Japanese prefectural governments were not sustainable across 1956-2007, though were sustainable across 1956-1989.

There are several literatures that discusses about the sustainability of the Japanese prefectural government debt, such as Doi (2004) [4], Sumi and Kawase (2007) [10], and Saito (2010) [9]. These studies, however, adjudge that government debt is sustainable if the current debt is less than the discounted present value of the primary balance. Moreover, these studies do not use long-term data and are not framed on the basis of fiscal stability rules articulated in seminal articles on fiscal solvency such as Bohn (1998) [2] $]^{2}$.

The rest of this paper is structured as follow. Section 2 reviews the previous literatures. Section 3 presents the empirical method and estimates and interprets the results. Finally, Section 4 concludes.

\section{Method for Fiscal Sustainability Test}

We use the method of Mendoza and Ostry (2008) [7] that has applied in a cross-country data test by Bohn (1998) [2]. We use 1955-2007 annual data for Japan's 47 prefectures $(i=1,2, \cdots, 47),(t=1955,1956, \cdots, 2007)$. The entire period can be divided into the period before the bubble burst (prefectural budgets were relatively balanced) and after the burst (reduced tax receipts necessitated additional fiscal expenditures). For each sample period, we estimate the equation

$$
s_{i, t}=\beta_{0 i}+\beta_{1} \tilde{y}_{i, t}+\beta_{2} \tilde{g}_{i, t}+\phi b_{i, t}+\varepsilon_{i, t},
$$

where $s_{i, t}$ is the primary surplus per gross prefectural products (GPP) in prefecture $i, \tilde{y}_{i, t}$ and $\tilde{g}_{i, t}$ denote temporary fluctuations in government spending and GDP, and $b_{i, t}$ is the government debt-to-GPP ratio.

Results of the Hausman-Wu test supported use of a fixed effects model with specific effects for each prefecture. This model allows constant terms that vary from prefecture to prefecture. Since there may be first-order serial correlation that varies across prefectures, we follow Mendoza and Ostry (2008) [7] in adjusting our estimate for first-order serial correlation by specifying that $\varepsilon_{i, t}=\rho_{i} \varepsilon_{i, t-1}+\eta_{i, t}$ (where $\eta_{i, t}$ is i.i.d). In addition, we make the White adjustment for heteroscedasticity using estimated prefectural standard errors and covariance.

The regressions use alternative measures of temporary fluctuations in government outlays and GDP. One is obtained by detrending the data using the Hodrick-Prescott filter. The resulting detrended series are labeled "output gap": $\left(y_{i, t}-y_{i, t}^{T}\right)$ and "government expenditure gap": $\left(g_{i, t}-g_{i, t}^{T}\right)$, which $y_{i, t}^{T}$ is the trend of output and $g_{i, t}^{T}$ is the trend of government expenditure. In the other, we employed "output gap" and "government expenditures gap" as explanatory variables.

\footnotetext{
${ }^{2}$ These literatures use the Japanese prefectural or municipal data after 1990.

${ }^{3}$ As for notation of the time, the local debt to GPP is at beginning, for the other variables are at the end.
} 
The second set follows Bohn (1998) [3] to construct measures of temporary fluctuations in output and government purchases that enter in the closed-form solution of Barro's (1986) [1] tax-smoothing model. These measures are defined as GVAR and YVAR for government purchases and output, respectively:

$$
\tilde{g}_{i, t}=G V A R_{i, t}=\frac{g_{i, t}-g_{i, t}^{T}}{g_{i, t}^{T}} \frac{g_{i, t}^{T}}{y_{i, t}}, \tilde{y}_{i, t}=Y V A R_{i, t}=\frac{y_{i, t}-y_{i, t}^{T}}{y_{i, t}^{T}} \frac{g_{i, t}^{T}}{y_{i, t}} .
$$

In these expressions, a subscript $T$ denotes the trend value of the corresponding variable.

\section{Result}

Table 1 shows the estimation results of Equation (1), for the period before the Japanese housing and stock market bubble ${ }^{4}$ burst (until 1989), and after the bubble burst (since 1990) ${ }^{5}$. Values in row I, column II represent the entire period. Those in row III, column IV pertain to pre bubble. Values in row V, column VI are post bubble. However, estimated values of the constant terms $\beta_{0, i}$ in Equation (1) are not reported ${ }^{6}$. As seen in Table 1, $\varphi$ takes a positive and significant valueonly for the period before the bubble burst. The estimated value of $\varphi$ is insignificant for the entire period and for the post-bubble period.

We derive the following two points. First, before the bubble burst the value of $\varphi$ is positive and significant, meaning that Bohn's (1998) [2] sufficient condition for sustainability was fulfilled. Second, post-bubble tax revenues fell until the early-to-mid-1990s, and public works were initiated as an economic stimulus. Fiscal discipline was absent, and Bohn's (1998) [2] conditions were not met. Finally, the Bohn (1998) [2] criteria were not met for the entire period because of the large post-bubble fiscal stimulus and increases in the chronic budget deficit. Thus, we see that the condition for sustainability of the fiscal policy reaction function under the assumption of linearity did not hold.

Table 1. Sustainability of prefectural government debt. (Dependent variable: Primary Balance/GPP).

\begin{tabular}{|c|c|c|c|c|c|c|}
\hline & I & II & III & IV & V & VI \\
\hline Local bond/GPP & $\begin{array}{l}-0.01 \\
(0.01)\end{array}$ & $\begin{array}{l}-0.011 \\
(0.002)\end{array}$ & $\begin{array}{c}0.08 \\
(0.015)^{* * *}\end{array}$ & $\begin{array}{c}0.067 \\
(0.014)^{* * *}\end{array}$ & $\begin{array}{c}0.02 \\
(0.028)\end{array}$ & $\begin{array}{l}-0.002 \\
(0.027)\end{array}$ \\
\hline $\begin{array}{l}\text { Output } \\
\text { gap }\end{array}$ & & $\begin{array}{c}1.8 \times 10^{-10} \\
\left(2.7 \times 10^{-10}\right)\end{array}$ & & $\begin{array}{c}1.8 \times 10^{-10} \\
\left(2.4 \times 10^{-10}\right)\end{array}$ & & $\begin{array}{c}2.1 \times 10^{-9} \\
\left(1.3 \times 10^{-9}\right)\end{array}$ \\
\hline $\begin{array}{l}\text { Government } \\
\text { expenditure } \\
\text { gap }\end{array}$ & & $\begin{array}{l}-3.5 \times 10^{-9} \\
\left(2.9 \times 10^{-9}\right)\end{array}$ & & $\begin{array}{l}-5.2 \times 10^{-10} \\
\left(5.1 \times 10^{-10}\right)\end{array}$ & & $\begin{array}{c}-3.7 \times 10^{-8} \\
\left(1.3 \times 10^{-8}\right)^{* * *}\end{array}$ \\
\hline YVAR & $\begin{array}{c}6.5 \times 10^{-7} \\
\left(2.8 \times 10^{-7}\right)^{* * *}\end{array}$ & & $\begin{array}{c}1.4 \times 10^{-7} \\
\left(4.6 \times 10^{-7}\right)\end{array}$ & & $\begin{array}{c}9.2 \times 10^{-7} \\
\left(4.1 \times 10^{-7}\right)^{* *}\end{array}$ & \\
\hline GVAR & $\begin{array}{c}-0.024 \\
(0.001)^{* * *}\end{array}$ & & $\begin{array}{c}-0.037 \\
(0.009)^{* * *}\end{array}$ & & $\begin{array}{l}-0.196 \\
(0.049)^{* * *}\end{array}$ & \\
\hline Adj. $R^{2}$ & 0.522 & 0.522 & 0.571 & 0.56 & 0.537 & 0.532 \\
\hline s.e. & 0.016 & 0.016 & 0.003 & 0.0029 & 0.025 & 0.025 \\
\hline Observations & 2292 & 2292 & 1448 & 1448 & 844 & 844 \\
\hline
\end{tabular}

Note: Columns I, II: 1956-2007, Columns III, IV: 1956-1989, Columns V, VI: 1990-2007. Figures in parentheses represent the standard deviation. In addition, ${ }^{*}$ denotes $10 \%$ significance, ${ }^{* *}$ denotes $5 \%$ significance, and ${ }^{* * *}$ denotes $1 \%$ significance. Serial correlation of error terms specific to the prefectural $\varepsilon_{i, t}=\rho_{i} \varepsilon_{i, t-1}+\eta_{i, t} \quad\left(\eta_{i, t} \sim\right.$ i.i.d $)$ was corrected by estimating. In addition, heteroscedasticity is fixed by White cross-section standard errors and covariance. Output gap and government spending gap are made by real GPP and real government expenditure extracted from trends of the Hodrick-Prescott filter, YVAR, GVAR is computed from the definition of Barro (1986) [1].

\footnotetext{
${ }^{4}$ Japanese housing and stock market bubble happened in the late 1980s.

${ }^{5}$ We investigate whether structural break causes in 1990 or not using Chow test and obtain the statistic significantly (i.e. 1\% significant) result that the structural break causes in 1990. In this paper, we define the term of pre bubble as 1955-1989 and that of post bubble as 1990-2007. At the same time, this paper adopts the panel unit root tests conducted by Im, Pesaran, and Shin (2003) [6]. In either case, GPP ratios for outstanding local government debt are I(1), versus GPP primary balance ratios I(0) (stationary).

${ }^{6}$ This paper has not shown the value of the constant term. Contact the author concerning such results as might be available.
} 


\section{Conclusions}

We obtain that fact that although the Japanese prefectural government finances in the aggregate were unsustainable throughout the entire period 1956-2007, they were sustainable during the truncated period ending in 1989.

It remains for a possibility to develop analytical method that advances the policy analysis in this paper. For example, Ostry et al. (2010) [8] estimates "Fiscal Space", which means government debt limit, using government budget constraint and fiscal stability rules. We will deal with as a future work.

\section{Acknowledgements}

We thank Nobuo Akai, Shun-ichiro Bessho, Takao Fujii, Isao Horiba, Yasushi Iwamoto, Takashi Kamihigashi, Yukihiro Nishimura,Shin Saito, Eiji Sumi and participants of the Public Economics Workshop at Kyoto. Hiraga gratefully acknowledges the support from Keio Gijuku Academic Development Funds.

\section{References}

[1] Barro, R.J. (1986) U.S. Deficits since World War I. Scandinavian Journal of Economics, 88, 195-222. http://dx.doi.org/10.2307/3440285

[2] Bohn, H. (1998) The Behavior of U.S. Public Debt and Deficits. Quarterly Journal of Economics, 113, 949-963. http://dx.doi.org/10.1162/003355398555793

[3] Bohn, H. (1998) Technical Appendix to: The Behavior of U.S. Public Debt and Deficits. mimeo.

[4] Doi, T. (2004) Economics of Fiscal Decentralization. Nihon Hyoron Sha, Tokyo. (In Japanese).

[5] Doi, T. (2007) Economics of Local Bond System. Nikkei Publishing Inc. (In Japanese).

[6] Im, K.S., Pesaran, M.H. and Shin, Y. (2003) Testing for Unit Roots in Heterogeneous Panels. Journal of Econometrics 115, 53-74. http://dx.doi.org/10.1016/S0304-4076(03)00092-7

[7] Mendoza, E.G. and Ostry, J.D. (2008) International Evidence on Fiscal Solvency: Is Fiscal Policy “Responsible”? Journal of Monetary Economics, 55, 1081-1093. http://dx.doi.org/10.1016/j.jmoneco.2008.06.003

[8] Ostry, J.D., Ghosh, A.R., Kim, J.I. and Qureshi, M.S. (2010) Fiscal Space. IMF Staff Position Note, 1 September 2010.

[9] Saito, Y. (2010) Disparity between Municipality for Economic Analysis. K.G. University Press, Hyogo. (In Japanese).

[10] Sumi, E. and Kawase. A. (2007) Investigation of Management of Local Public Finance and Sustainability in Post 90s Japan: The Real Provision for Finance of Japanese Prefectural Public Finance. HIA Discussion Paper, Hosei University, Tokyo. (In Japanese). 


\section{Appendix}

We extract the prefectural public finance data from Annual Statistics of Local Public Finance (called "Chihouzaiseitoukeinenpou" in Japanese) and Gross Prefectural Product (GPP) and Prefectural Aggregate Government Expenditure which we use it to make YVAR, GVAR and government expenditure gap of it. As for conjugation 68SNA and 93SNA, we adjust the values of 68SNA before 1995 to multiply them by (GPP of 93SNA in 1996/ GPP of 68SNA in 1996). Since there are several missing variables about GPP in Fukushima, Saitama, Okayama, and Okinawa, we use unbalance panel estimation.

As for calculating the primary balance, we use the method of Doi (2007) [5] as following:

Primary balance $=$ National debt service + Reserve for funds + Kuriirejyuyoukin of the previous year

-Issuing new local government debt - Balance brought forward - Reversal of reserve fund

+ Total annual revenue - Total annual expenditure

We deduct reserve for funds from the amount of local government debt to keep consistency with flow (i.e. primary balance) and stock (i.e. local government debt) of government budget. We show the values of the amount of local government debt, Local allocation tax, Primary balance, Nominal and Real GPP and Real government expenditure in Table A.

Table A. Descriptive statistics of data (100 million yen, observations: 2344 (Unbalanced Panel), rounded to the closest whole number).

\begin{tabular}{|c|c|c|c|c|}
\hline Item & Average & S.D & Max & Minimum \\
\hline The amount of local government debt & 5937 & 9142 & 80,219 & 91 \\
\hline Local allocation tax & 1191 & 1025 & 8363 & 0 \\
\hline Primary balance & -281 & 4779 & 7987 & -7791 \\
\hline Nominal GPP & 57,387 & 102,838 & 923,005 & 374 \\
\hline Real GPP & 67,375 & 106,932 & 994,093 & 1914 \\
\hline Real government expenditure & 15,447 & 18,263 & 146,763 & 620 \\
\hline
\end{tabular}

